\title{
Accumulation of Trace Metals, Petroleum Hydrocarbons, and Polycyclic Aromatic Hydrocarbons in Marine Copepods from the Arabian Gulf
}

\author{
N. M. Nour El-Din, ${ }^{1}$ M. A. R. Abdel-Moati ${ }^{2}$ \\ 1 Oceanography Department, Faculty of Science, Alexandria University, Moharam \\ Bey, Alexandria, Egypt \\ 2 Scientific and Applied Research Center (SARC), University of Qatar, Doha Post \\ Office Box 2713, Qatar
}

Received: 4 April 2000/Accepted: 11 October 2000

Marine plankton play a major role in the interaction and transfer of pollutants in marine systems. Their use as biomonitors is a quantification of the ability to regulate pollutant levels and variations. Though being an important food item for many fishes, most knowledge concerning zooplankton in the Arabian Gulf waters is concerned with abundance, distribution and species composition (Michel et al., 1986; Ghobashy et al., 1994).

The coastal waters of Qatar are subjected to different types of stress. The southeastern borders receive about $300 \times 10^{9} \mathrm{~m}^{3} / \mathrm{yr}$ of industrial discharge mainly from fertilizer and petrochemical industries. In addition, along the southeastern coast two main oil terminals are used for loading oil tankers (Abdel-Moati and Falamarzi, 1996). Off the capital, Doha, the marine area has been subjected to land runoff as well as discharge from fishing and trade harbors. Since 1996, the northeastern coast is subjected to industrial discharge from a natural-gas-based industrial complex. Due to their location, the northern and northeastern areas are also intermittently subjected to oil spills originating from illegal disposal of ballast and bilge water from oil tankers (Al-Ansari, 1998). The western coast, characterized by elevated salinity, is less exposed to pollution stress. As a part of the Gulf circulation, the northeastern coast receives water from the anticlockwise gyre entering through Hormuz passing the Iranian coast. Along the eastern coast water moves parallel to the coastline from north to south. The northern area is affected by a coastal current from Salwa bay.

In this study, zooplankton samples were collected from the coastal waters of Qatar during winter and summer 1998 to assess the impact of growing industrialization on the bioaccumulation of trace metals, total petroleum hydrocarbons (TPHCs) and polycyclic aromatic hydrocarbons (PAHs) in copepods, the dominant zooplankton group and main food for fish in the Arabian Gulf.

\section{MATERIALS AND METHODS}

Surface Zooplankton samples were collected during daytime using a $120 \mu \mathrm{m}$ zooplankton net $(50 \mathrm{~cm}$ diameter ring) from four different locations, covering the coastal waters of Qatar (Messaieed, Doha Harbor, Ras Laffan and the western coast 


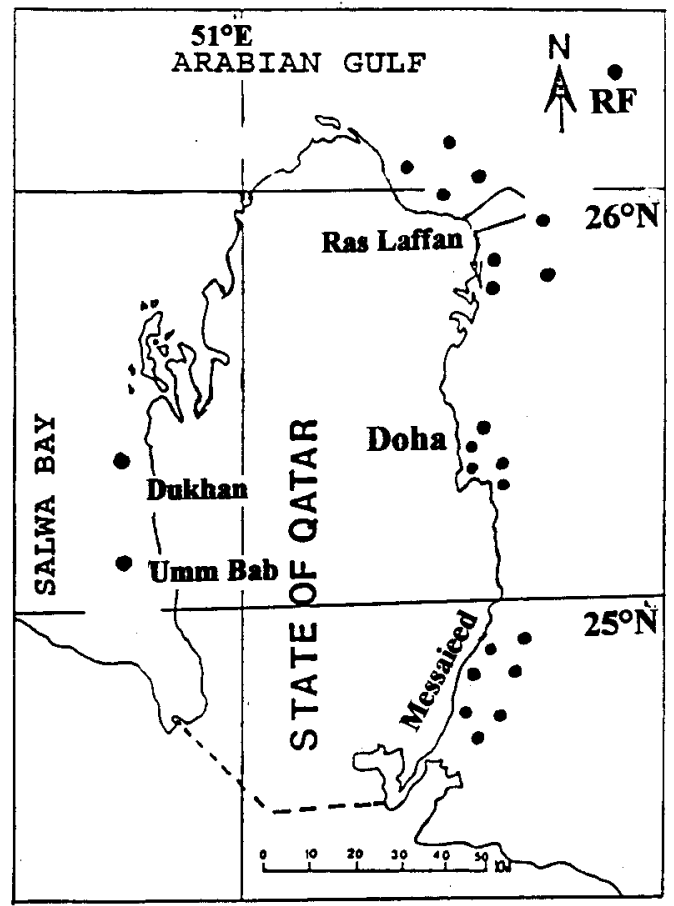

Figure 1. The coastal waters of Qatar showing the sampling stations.

i.e. Dukhan and Umm Bab) in addition to one reference location collected $50 \mathrm{Km}$ northeast of Qatar apart from any landbased activity (Figure 1). Samples for metals analyses were collected in acid-cleaned PVC bottles that had been rinsed with deionized water, while those for TPHCs and PAHs were collected in glass containers that had been washed in soap, deionized water, rinsed in methylene chloride (Optima) and baked in an oven at $200^{\circ} \mathrm{C}$. Samples were preserved in an ice box and a fridge at $<4^{\circ} \mathrm{C}$ until analyses. Copepods subsamples were obtained by a Stempel pipette. Metals were analyzed in freeze-dried copepods $(0.2 \mathrm{~g})$ using the concentrated nitric acid wet digestion method (MOOPAM, 1989). The residue was taken up in $2 \% \mathrm{HNO}_{3}$. Samples were measured using a Perkin Elmer Atomic Absorption Spectrophotometer Model Analyst 700 equipped with autosampler and graphite furnace. Results of analysis of four replicate of Certified Reference Material (CRM 414) for Trace Elements in Plankton from Community Bureau of Reference (BCR) were close to certified values (Table 1).

Freeze-dried subsamples $(\sim 5 \mathrm{~g})$ for determination of $\mathrm{n}$ - alkanes $\left(\mathrm{C}_{10}-\mathrm{C}_{32}\right)$ were saponified and extracted by hexane (Optima) for $20 \mathrm{~h}$, cleaned using activated silica gel and concentrated to $1 \mathrm{~mL}$ using a Kuderna Danish Concentrator following EPA Method 418.1, Revision 1.1 (Solutions Software Co., 1998). Concentrations of nalkanes were obtained using HP Gas Chromatograph (GC 6890 ) provided with Flame Ionization Detector (FID), Auto - injector and HP - ChemStation. Internal Standards $C_{18.1}$ and $C_{32}$ were added for all analyzed samples. The analysis of five replicates from the Reference Material (IAEA-142 Mussel Homogenate) gave results within those of the certified values (Table 1). QA/QC requirements for 

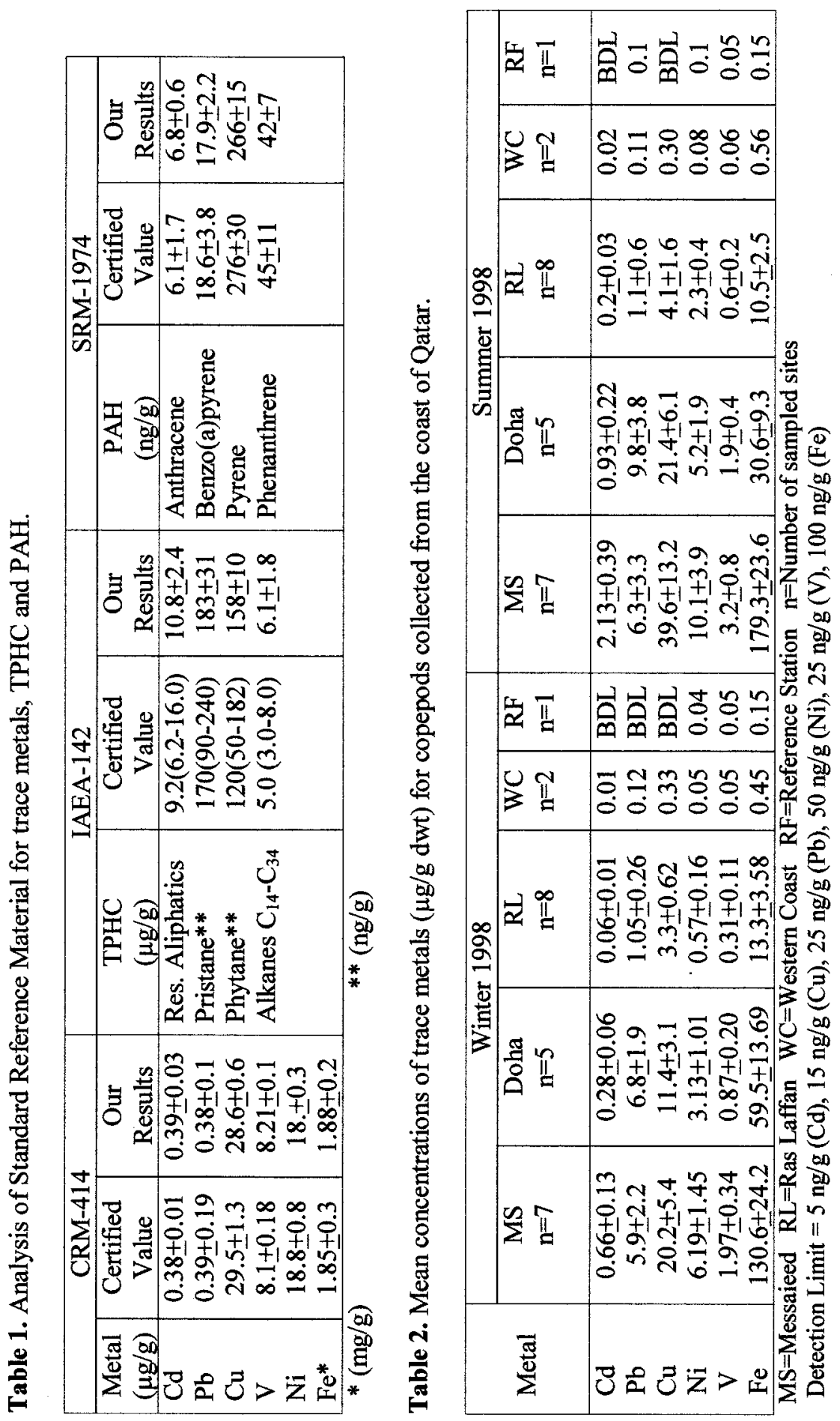
analysis of marine organisms are detailed in Reference Method \# 57 UNEP/IOC/IAEA/FAO (1990).

For determination of PAHs subsamples $(\sim 5 \mathrm{~g})$ were extracted by methylene chloride, ten times the weight of the sample. The extract was reduced to about $1 \mathrm{~mL}$ using Kuderna Danish and pure nitrogen (99.995\%). Internal Standards (Naphthalene- $d_{8}$ and Phenanthrene- $d_{10}$ ) were added to check recovery. Efficiencies varied between 84 and $92 \%$. Extracts were measured using the HP Gas Chromatography/Mass Spectrometric Detector (GC HP 5890 Series II + MS 2972) using EPA Method 625 (Solutions Software Co., 1998). Enviroquant software was used for data acquisition. Standards were obtained from PolyScience and Ultra Scientific. Triplicate analyses were carried out for each sample. QC was carried out with each set of samples for checking performance through running blanks and examining Standard Reference Material 1974 (Organics in Mussel Tissue) with each batch of 10 samples (Table 1 ).

\section{RESULTS AND DISCUSSION}

Copepods dominated the zooplankton community along the Qatari coastline composing more than $73 \%$ of the total zooplankton. Copepods numerical abundance was 4714 to $8004 \mathrm{ind} / \mathrm{m}^{3}$ for Doha Harbor, 3088 to $5470 \mathrm{ind} / \mathrm{m}^{3}$ for Ras Laffan area, 2248 to $4864 \mathrm{ind} / \mathrm{m}^{3}$ for the western coast, 1862 to $3010 \mathrm{ind} / \mathrm{m}^{3}$ opposite MIA and 2198 to $5080 \mathrm{ind} / \mathrm{m}^{3}$ for the Reference Station. Among copepods, calanoids composed $42 \%$ of the total copepod population, followed by cyclopoids (36\%) and harpacticoids (22\%). The most abundant calanoids were Paracalanus crassirostris and $P$. aculeatus, while Oithona spp. and Oncaea spp. were the most abundant cyclopoids and Euterpina acutifrons is the dominant harpacticoid.

With the exception of $\mathrm{Pb}$, highest levels of all metals (Table 2) were recorded for copepods collected opposite to Messaieed Industrial Area (MIA). The elevated Fe concentrations in the water column opposite the MIA, derived from the iron \& steel industry (loading and unloading raw material), are reflected in its accumulation in copepods, reaching $179.3 \pm 23.6 \mu \mathrm{g} / \mathrm{g}$ during summer, especially in the near-shore waters. Copepods collected from Doha Harbor (including fishing and trade activities and surrounded by the main highway of the city) showed significant accumulation of $\mathrm{Pb}$ during summer i.e. $9.8 \pm 3.8 \mu \mathrm{g} / \mathrm{g}$ and winter i.e. $6.8 \pm 1.9 \mu \mathrm{g} / \mathrm{g}$. Leaded gasoline is currently used as fuel for cars in Qatar. Abdel-Moati (1998) recorded elevated levels of trimethyllead and triethyllead in Doha Harbor, especially at nearshore locations close to traffic lights. Enhanced lead levels were also recorded in phytoplankton (range $1.15-3.44 ; \mathrm{av} .2 .07 \mu \mathrm{g} / \mathrm{g}$ ) collected opposite the MIA (Abdel-Moati \& Falamarzi, 1996). Generally, most of the detected values of $\mathrm{Cd}$ fluctuated between $0.06 \mu \mathrm{g} / \mathrm{g}$ for the northeastern coast and $2.13 \mu \mathrm{g} / \mathrm{g}$ for the southeastern coast. $\mathrm{Cu}$ like $\mathrm{Cd}$ reaches the coastal waters through industrial discharge from petrochemical and fertilizer industries. Copepods collected opposite the MIA sustained a maximum level of $39.6 \mu \mathrm{g} / \mathrm{g}$ of $\mathrm{Cu}$ during summer compared to undetectable levels for copepods collected from the Reference station (Table 2). The exposure of the southeastern coast to several oil spills during loading and 
unloading activities through mooring buoys is a main cause of $\mathrm{Ni}$ and $\mathrm{V}$ accumulation (average concentrations $0.54-10.1 \mu \mathrm{g} \mathrm{Ni} / \mathrm{g}$ and $0.31-3.2 \mu \mathrm{g} \mathrm{V} / \mathrm{g}$ ) in copepods. The ratios of $\mathrm{Ni} / \mathrm{V}$ accumulated in copepods collected from oil spill impacted areas i.e., $\sim 3: 1$ is close to that observed for oil, suggesting that copepods could be used as indicators for oil contamination. This suggestion is supported by the significant correlation between both metals $(r=0.8793, p<0.001)$ in copepods collected from the whole area. Highly polluted copepods were observed in areas continuously receiving industrial outfalls or practicing oil activities suggesting that copepods in general do not transport pollutants from one location to another. Average concentration factors (CF) i.e. concentration in organism/concentration in water were $31,5,21,75,23$ and 38 for $\mathrm{Cd}, \mathrm{Pb}, \mathrm{Cu}, \mathrm{Ni}, \mathrm{V}$, and $\mathrm{Fe}$, respectively, indicating their ability to accumulate metals even when present at low concentrations. Hajderi et al. (1995) recorded elevated levels of $\mathrm{Pb}(95 \mu \mathrm{g} / \mathrm{g}), \mathrm{Cd}$ $(4.8 \mu \mathrm{g} / \mathrm{g})$ and $\mathrm{Ni}(20.3 \mu \mathrm{g} / \mathrm{g})$ for zooplankton from the Adriatic Sea compared to the present concentrations; while, lower averages were observed for $\mathrm{Cu}(28.3 \mu \mathrm{g} / \mathrm{g})$ and $\mathrm{Fe}(109.91 \mu \mathrm{g} / \mathrm{g})$. Fisher et al. (2000) recorded a mean Cd concentration of 2.5 $\mu \mathrm{g} / \mathrm{g}$ for copepods collected off Monaco coast.

Table 3 summarizes the results of hexane extractable organic matter (HEOM) as well as the levels of TPHCs in $\mu \mathrm{g} / \mathrm{g}$ during both surveys. Oil contamination in copepods was restricted to the southeastern coast where crude oil loading activities takes place. TPHCs fluctuated between $3.3-66.2 \mu \mathrm{g} / \mathrm{g}$ and $10.4-135.5 \mu \mathrm{g} / \mathrm{g}$ during winter and summer, respectively. The Messaieed marine area is continuously subjected to illegal discharges of ballast and bilge waters from oil tankers and minor accidents at oil terminals. Several oil spill incidents occurred in the area during the last five years. Measured levels of TPHCs in plankton varied between 0.3 and 263 $\mu \mathrm{g} / \mathrm{g}$ dry weight in the open sea and between 1.4 and $1586 \mu \mathrm{g} / \mathrm{g}$ dry weight in coastal waters (McIntyre and Whittle, 1977). Sen Gupta et al. (1993) recorded levels between $0.63-10.88$ (av. 3.11) $\mu \mathrm{g} / \mathrm{g}$ and 4.52-144.7 (av. 44.87) $\mu \mathrm{g} / \mathrm{g}$ dry weight in zooplankton collected during two cruises from the Arabian Sea after the Gulf War.

The increase of TPHC in copepods is correlated with the amount of oil in water. The CF for TPHC ranged between 25 and 165. Effects of oil on zooplankton are well-documented (Teal and Howarth, 1984), although most of these effects appear to be only transient (Clark, 1992). Conover (1971) observed that zooplankton ingest large quantities of small oil droplets and could eliminate them in the form of fecal matter. Assessing that hydrocarbons are accumulated through direct uptake from seawater or through phytoplankton diets is difficult. The presence of copepods in the euphotic zone encourage their transfer through the food chain and thus TPHC accumulation especially in pelagic fish (Abdel-Moati and El-Said, 1997).

Aliphatic hydrocarbons (n-alkanes serries from $\mathrm{C}_{10}-\mathrm{C}_{32}$ as well as the isoprenoids: pristane and phytane) were measured. Pristane and phytane were present in $42 \%$ of the analyzed samples. Pristane : Phytane ratio ranged from 0.22 to 16.47 . Ratios $<1$ were recorded in 15 samples indicating a petrochemical origin of these aliphatics. The presence of pristane could be attributed to biogenic origin of hydrocarbons 


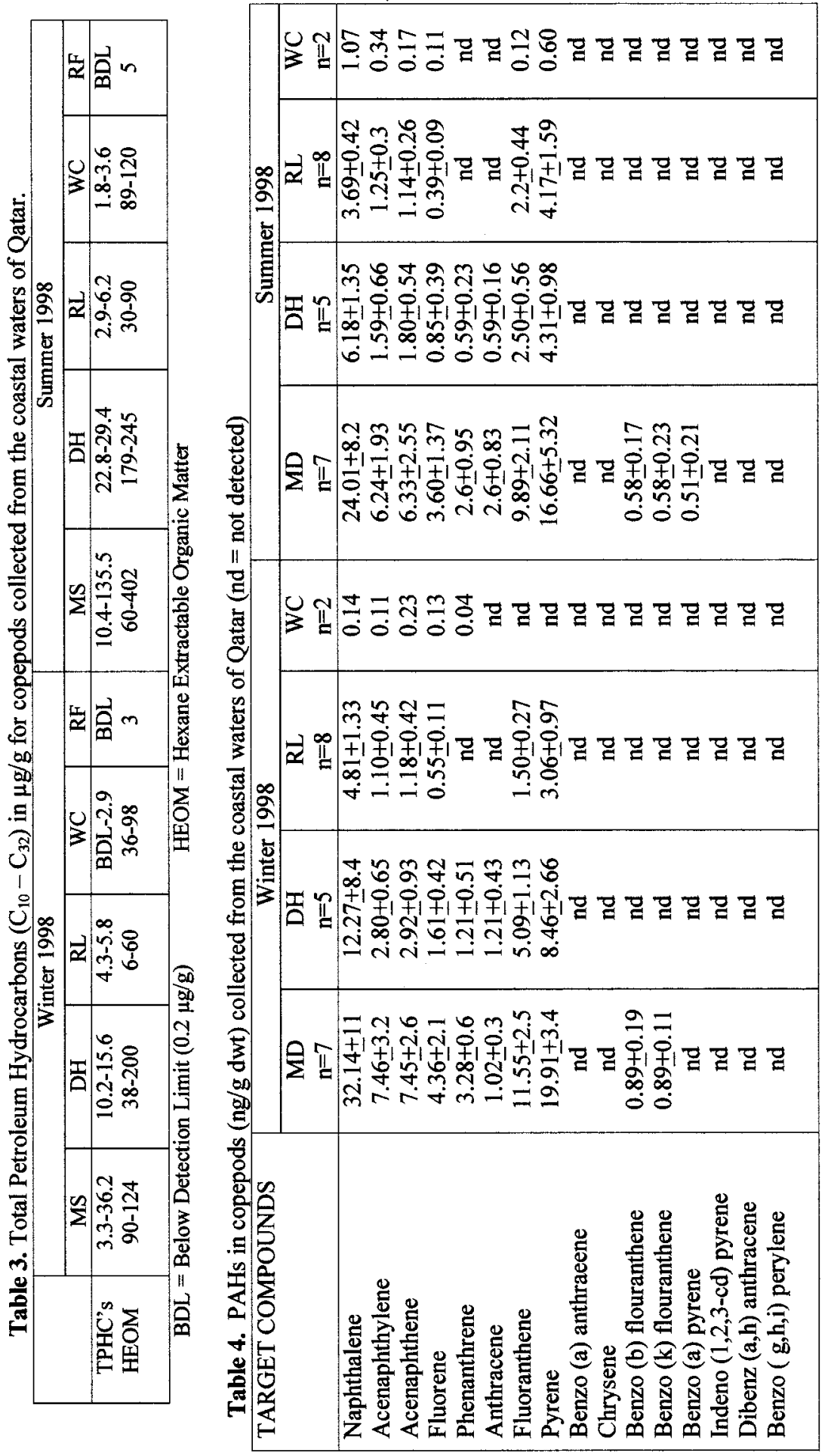


synthesized by copepods (planktonic source). Total n-alkanes (sum of all quantified compounds) varied between 4.1 and $16.8 \mu \mathrm{g} / \mathrm{g}$ and from 2.4 to $52.6 \mu \mathrm{g} / \mathrm{g}$ for copepods collected from Ras Laffan and Messaieed marine areas, respectively. Copepods collected from Doha Harbor sustained 6.9 to $76.1 \mu \mathrm{g} / \mathrm{g} \mathrm{n}$-alkanes, while the western coast levels varied between $n d-3.11 \mu \mathrm{g} / \mathrm{g}$. Unresolved complex mixture (UCM) was absent in most of the analyzed samples indicating the relative freshness (days) of the exposure of copepods to oil contamination. Readman et al. (1986) used the UCM as a measure of chronic, degraded oil contamination. Variations in n-alkanes could be related to biometric measurements, sex and type of available food during sampling. $\mathrm{C}_{10}$ was detected in $23 \%$ of samples (range $0.1-2.6 \mu \mathrm{g} / \mathrm{g}$ ) while $\mathrm{C}_{12}$ was detected only in 4 samples (range $0.18-0.22$ ). Other alkanes were recorded in all samples. Unfortunately, lack of prior sampling around Qatar and within the Gulf during earlier years precludes making temporal comparisons.

Results of analysis of PAHs in copepods are presented in Table 4. Of the sixteen PAH target compounds, Indeno (1,2,3-cd) pyrene, Dibenz $(\mathrm{a}, \mathrm{h})$ anthracene, Benzo ( $g, h, I)$ perylene, Benzo (a) anthracene and Chrysene were not detected in any of the analyzed samples; while, Benzo (b) fluoranthene and Benzo (k) flouranthene where only detected in samples collected opposite the MIA. Naphthalene followed by pyrene and fluoranthene are the dominant PAHs measured in detectable levels of the analyzed samples. Naphthalene and pyrene constituted between $28-39 \%$ and $22-$ $32 \%$ of the PAHs. On the other hand, Acenaphthylene, Acenaphthene constituted between $5-10 \%$ of PAHs. Fluoranthene generally constituted between $10-15 \%$ of PAHs. The mean levels decreased in value with the collection site as follows: MIA> Doha Harbor $>$ Ras Laffan Industrial Area > western Coast $>>$ Reference station. The general predominance of low molecular weight PAHs in the samples support a petroleum source.

PAHs are dangerous pollutants causing carcinogenic and mutagenic effects. They are formed in the marine environment through organic matter pyrolysis, generation in sedimentary organic matter and fossil fuels as well as biosynthesis by organisms (La Flamme \& Hites, 1978). Their appearance in copepods is through absorption and accumulation from water. Cooling water mixed with industrial discharge from petrochemical and fertilizer industries contributes to hydrocarbon levels. Hites (1976) observed that high levels of aromatic and high molecular weight aliphatic hydrocarbons are indicative of petroleum pollution. PAHs were not highly accumulated in phytoplankton from Ras Laffan Marine area (Abdel-Moati, unpublished data), indicating that copepods accumulate PAHs through the water column by absorption rather than through the food chain. Based on the qualitative classification of PAH carcinogenity (IARC, 1987), detected PAHs classified as having sufficient or limited evidence for carcinogenity [Benzo (a) pyrene, Benzo (a) anthracene and chrysene], were lower in concentration and frequency of detection than those classified as having insufficient or no evidence for carcinogenity [Fluoranthene, anthracene, phenanthrene and pyrene]. 


\section{REFERENCES}

Abdel-Moati MAR (1998) Alkyllead in the coastal environment of Qatar. Reg Conf on the Mar Environ of the Gulf. Doha Qatar 12-15 December,1998:56

Abdel-Moati MAR, Al-Said TF (1997) Bioaccumulation of some pollutants in marine organisms from Qatari waters. Inter Conf on Biology of Coastal Environments, Bahrain 6-9 April, 1997: 25

Abdel-Moati MAR, Falamarzi M (1996) Accumulation of lead in Umm Said marine area (Qatar), Arabian Gulf. Fres Environ Bull 5:196-201

Al-Ansari IS (1998) Impact of landbased discharge on the distribution of nutrient salts off the Qatari coast. M.Sc. Thesis, University of Wales (Bangor), $167 \mathrm{pp}$

Clark RB (1992) Marine Pollution, $3^{\text {rd }}$ ed. Clarendon Press, Oxford, UK

Conover RJ (1971) Some relations between zooplankton and bunker crude oil in the Chedabucto Bay following the wreck of the tanker Arrow. J Fish Res B Canada 28: $1327-1330$

Fisher NS, Stupakoff I, Wilhelmy SS, Wang W, Teyssie J, Fowler SW, Crusius J (2000) Trace metals in marine copepods:a field test of a bioaccumulation model coupled to laboratory uptake kinetics data. Mar Ecol Prog Ser, 194:211-218.

Ghobashy AFA, Nour El-Din NM, El-Sadah Sh (1994) On zooplankton in Qatari waters. J Egypt German Soc Zool 15 (D): 325-345

Hajderi E, Storelli MM, De Natle G, Marcotrigiano GO (1995) Seasonal variations of metals in zooplankton in the coastal waters of the south Adriatic Sea. Rapp Comm Int Mer Medit, 34:138

Hites R (1976) Sources of PAHs in the aquatic environment. In: Sources, effect and sinks of hydrocarbons in the aquatic environment. American Instit Biolo Sci, Washington D.C., $325 \mathrm{pp}$

International Agency for Research on Cancer (IARC) (1987) IARC Monogr Eval Carcinog Risk Chem Hum Suppl 7, 213 pp

La Flamme RE \& Hites RA (1978) The global distibution of polycyclic aromatic hydrocarbons in recent sediment. Geoch et Cosmoch Acta 42:289-303

McIntyre AD, Whittle KJ (1977) Petroleum hydrocarbons in the marine environment.Rapport Revnue Counsel International Exploration de Mer171: 72

Michel HB, Behbehani M, Herring M, Arar D, Shoushani M, Brakoniecki TC (1986) Zoolankton in the western Arabian Gulf south of Kuwait waters. Kuwait Bull Mar Science 8:1-86

MOOPAM (1989) Manual of Oceanographic Observations and Pollutant Analysis Methods, ROPME, Safat, Kuwait, 337-355

Readman JW, Preson MR, Mantoura RFC (1986) An integrated technique to quantify sewage oil and PAH pollution in estuarine \& coastal environments. Mar Pollut Bull 17: 298-308

Reference Method No. 57 UNEP/IOC/IAEA/FAO (1990) Contaminant monitoring programs using marine organisms: Qual Assur Good Lab Prac. UNEP, $112 \mathrm{pp}$

Sen Gupta R, Fondekar SP, Alagsamy R (1993) State of oil pollution in the Northern Arabian Sea after the 1991 Gulf oil spill. Mar Pollut Bull 27: 85-91

Solutions Software Co. (1998) EPA Methods \&Guidance, $3^{\text {rd }}$ ed., Florida, USA Teal JM, Howarth RW (1984) Oil spill studies: A review of ecological effects. Environ Manag 8: 27-44 